Available Online at

http:// www.bioline.org.br/ja
J. Appl. Sci. Environ. Mgt. 2004

Vol. 8 (1) 37 - 44

\title{
Mineralogy of Tailings Dump around Selebi Phikwe Nickel-Copper Plant, Botswana
}

\author{
${ }^{1 *}$ EKOSSE, G; ${ }^{2}$ VAN DEN HEEVER, D J; ${ }^{3}$ DE JAGER, L; ${ }^{4}$ TOTOLO, O
}

\author{
${ }^{1 *}$ Department of Geology, University of Botswana, P/Bag 0022 Gaborone, Botswana \\ ${ }^{2}$ VDH Industrial Hygiene CC.PO. Box 26792 Langenhoven Park, 9330, Free State, South Africa \\ ${ }^{3}$ Department of Environmental Health, Technikon Free State, P/Bag X20539 Bloemfontein, Free State, South Africa \\ ${ }^{4}$ Department of Environmental Science, University of Botswana, P/Bag 0022 Gaborone, Botswana
}

\begin{abstract}
This study aimed at mineralogically characterizing the tailings dump emanating from the mining and smelting of nickel-copper (Ni-Cu) at Selebi Phikwe, Botswana, Southern Africa. Samples of tailings dump around the Selebi Phikwe Ni-Cu plant were studied using petrographic microscopy and X-ray Powder Diffraction (XRPD) technique. The tailings dump comprised of the following minerals: nickelblodite, pyrrhotite, quartz, pentlandite, malachite, chalcopyrite, actinolite, cristobalite, tremolite, kaolinite, mica and albite. Nickelblodite and malachite were mineralized from the primary ore minerals in the tailings dump. The sulfur-rich minerals contained in the tailings dump serve as principal promoting sources for acid mine drainage in the immediate surrounding environment. Consequently, aspects of pollution management such as phytoremediation and phytomining, and environmental desulfurization could be introduced as pollution control measures at Selebi Phikwe.@JASEM
\end{abstract}

Botswana is one of Africa's top three mineral producers by value, including South Africa and the Democratic Republic of Congo. Its mining industry provides employment for 10000 Batswana (National Census, 1991). Diamond, soda ash, gold and Ni-Cu remain the mainstay of the mining industry in Botswana. However, recent growth in mining activities in the country has generated a corresponding increase in tailings dump and other contaminants that are considered as environmental pollutants. The Selebi Phikwe $\mathrm{Ni}-\mathrm{Cu}$ mine area which is of concern is located geographically between longitudes $27^{\circ} 47^{\prime}$ East and $27^{\circ} 53^{\prime}$ East, and latitude $22^{\circ} 55^{\prime}$ South $22^{\circ} 00^{\prime}$ South (Figure 1). Mining and smelting activities may pose there as sources of environmental contamination. Previous studies conducted at Selebi Phikwe were directed at understanding the petrogenesis (Brown, 1987), structural geology (Gallon, 1986), and mineralogy (Nkoma and Ekosse, 1998; 1999; 2000) of the orebodies. X-ray powder diffraction studies of $\mathrm{Ni}-\mathrm{Cu}$ orebodies (Nkoma and Ekosse, 1999; 2000) and soils (Ekosse et al., 2003), and particulate air matter (Ekosse et al., 2004) have also been conducted. Over the past years, there has been growing concern on

*Corresponding author: E-mail: GEkosse@excite.com

Tel: 002673552569 (Office), 0026771609489 (Cell)

Abstract available Online at http:// www.ajol.info some possible environmental implications resulting from the mining and extraction activities. In this study, an attempt was made to mineralogically by XRPD characterize the tailings dump and determine any possible implications to the environment.

\section{MATERIALS AND METHODS}

Samples And Sampling: Sampling was done twice monthly from January to July 2000. Tailings dump samples were collected from the tailings dump mount close to the concentrator/smelter plant. Three representative samples were chosen from the tailings dump at each sampling period. Two of the three samples were collected close to the sides and one was taken from the centre of the tailings dump, giving a total of 42 tailings dump samples collected for analyses. A hand shovel and a trowel were used to collect the samples. Sampling was done at about 5 $\mathrm{cm}$ from the surface of the tailings dump mount, and at the sides taking into consideration the altitude of the dump, which was close to $6 \mathrm{~m}$. Each sample was placed in a $14 \mathrm{~cm}$ X $12 \mathrm{~cm}$ Hubco Sentry environmental sample bag, and transported to Gaborone. The samples were then placed overnight in a drier $\left(60^{\circ} \mathrm{C}\right)$ to eliminate surface moisture. 


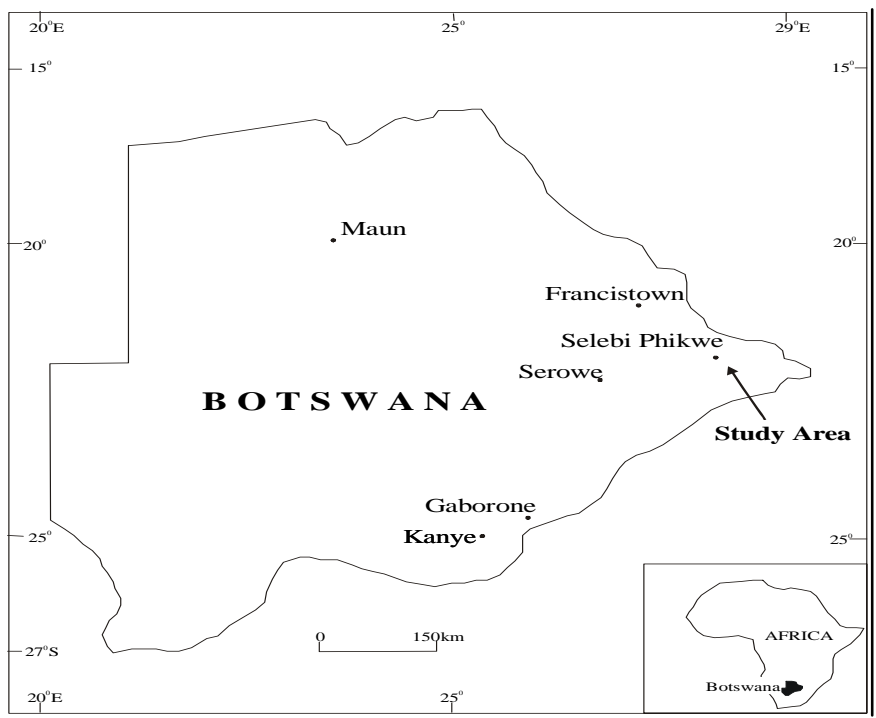

Fig 1: Map of Botswana showing where Selebi

Field observation: A Wards 10X hand lens was used to examine hand specimens of tailings dump. The shape and size of the tailings dump mount were visually observed as well as the color of the mineral crystals. All the observations were carried out at the sampling sites on the same day and time that samples were obtained for laboratory analyses.

Descriptive mineralogy: The optical microscopy technique was used for descriptive analyses of samples of tailings dump. The process involved testing for hardness, cleavage, fracture, color, streak, luster and crystal appearance. A Leitz Ortholux II Pol-BK petrographic microscope was used for descriptive mineralogy of the samples.

$X$-ray powder diffraction analyses: The mineral phases in the tailings dump were identified using XRPD techniques. A Philips PW 3710 XRPD system with a $\mathrm{Cu}-K_{a}$ cathode radiation source was used at
$40 \mathrm{kV}$ and $45 \mathrm{~mA}$. Samples were scanned from $2^{\circ}$ to $70^{\circ} 2 \theta$

\section{RESULTS}

Field observations: The tailings dump mount is continuously built from waste products of the mining and processing of the ore. The surface of the tailings dump mount was exposed to wind erosion. Small, dark and brassy yellow pseudo-tetragonal crystals of chalcopyrite and acircular green films of malachite could visibly be detected as constituents of the tailings dump. Hand specimens of the tailings dump samples, observed by using a hand lens, showed subangular quartz grains and crystals of greyish green amphiboles.

Descriptive mineralogy: Mineral constituents of hand specimens of the tailings dump were viewed under the microscope. Actinolite, albite, cristobalite, chalcopyrite, malachite, pyrite, pyrrhotite, tremolite and pentlandite were identified and have been in Table 1.

Table 1: Descriptive petrography of the minerals occurring in the tailings dump from the Ni-Cu orebodies.

\begin{tabular}{|c|c|c|c|c|c|c|c|}
\hline Mineral & $\begin{array}{l}\text { Hardness } \\
\text { (Mohr scale) }\end{array}$ & Cleavage & Fracture & Color & Streak & Luster & Crystal appearance \\
\hline Actinolite & $5-6$ & Good & $\begin{array}{l}\text { Uneven to } \\
\text { subconchoidal }\end{array}$ & $\begin{array}{l}\text { Light to } \\
\text { blackish green }\end{array}$ & White & Vitreous & Monoclinic \\
\hline Albite & $6-6.5$ & Distinct & Uneven & $\begin{array}{l}\text { White to } \\
\text { colorless }\end{array}$ & White & $\begin{array}{l}\text { Vitreous to } \\
\text { pearly }\end{array}$ & Triclinic \\
\hline Cristobalite & 7 & None & Conchoidal & $\begin{array}{l}\text { Colorless to } \\
\text { gray }\end{array}$ & White & Vitreous & Tetragonal \\
\hline Chalcopyrite & $3.5-4$ & Poor & Uneven to conchoidal & Brassy yellow & $\begin{array}{l}\text { Green to } \\
\text { black }\end{array}$ & Metallic & Tetragonal \\
\hline Malachite & $3.5-4$ & Good & Uneven & Emerald green & Light green & $\begin{array}{l}\text { Vitreous to } \\
\text { silky }\end{array}$ & Monoclinic \\
\hline Pyrite & $6-6.5$ & $\begin{array}{l}\text { None } \\
\text { distinct }\end{array}$ & Conchoidal to uneven & Pale yellow & $\begin{array}{l}\text { Green to } \\
\text { black }\end{array}$ & Metallic & Cubic \\
\hline Pyrrhotite & $3.5-4.5$ & None & $\begin{array}{l}\text { Uneven to } \\
\text { subconchoidal }\end{array}$ & Bronze yellow & $\begin{array}{l}\text { Dark gray to } \\
\text { black }\end{array}$ & Metallic & Hexagonal \\
\hline Tremolite & $5-6$ & Good & $\begin{array}{l}\text { Uneven to } \\
\text { subconchoidal }\end{array}$ & Colorless white & White & Vitreous & Monoclinic \\
\hline Pentlandite & $3.5-4$ & None & Uneven to conchoidal & $\begin{array}{l}\text { Light bronze } \\
\text { yellow }\end{array}$ & $\begin{array}{l}\text { Bronze to } \\
\text { brown }\end{array}$ & Metallic & Isometric \\
\hline
\end{tabular}


$X$-ray powder diffraction analyses: The following minerals were found to be unevenly distributed in the samples of the tailings dump: nickelblodite, pyrrhotite, quartz, pentlandite, malachite, chalcopyrite, actinolite, cristobalite, tremolite, kaolinite, mica and albite (figures 2, 3 and 4). Samples from the older part of the tailings dump were deprived of pyrrhotite, pentlandite and chalcopyrite. The samples contained mainly malachite, cristobalite and nickelblodite. The XRPD analyses revealed the following mineral phases in the mineral content of the more recent part of the tailings dump: pyrrhotite, pentlandite, actinolite, malachite and chalcopyrite. Samples of the tailings dump obtained from the sides of the tailings mount were found to contain traces of phyllosilicate minerals such as kaolinite and mica, as well as tremolite, albite and actinolite.

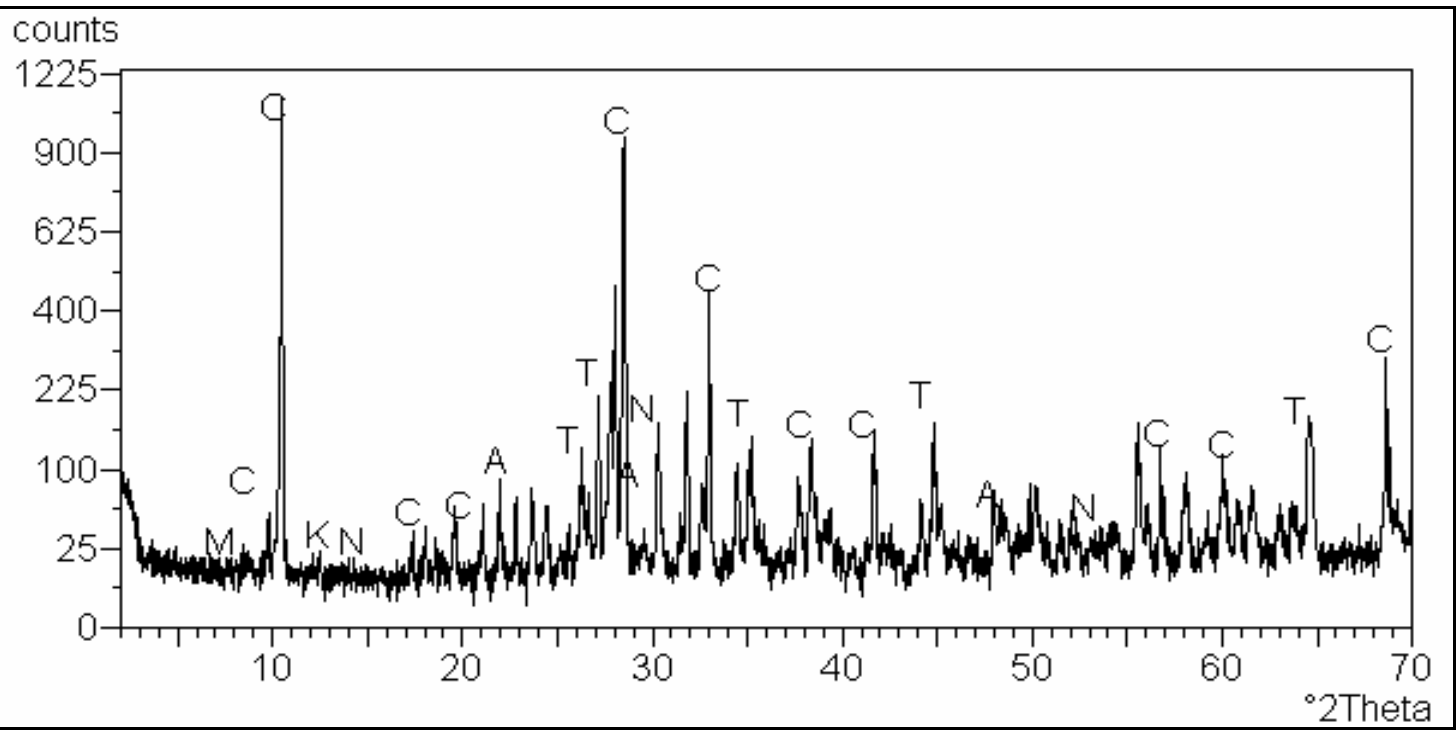

Fig 2: X-ray powder diffractogram of representative tailings dump sample obtained from site one of tailings dump (K is kaolinite, $\mathrm{N}$ is albite, $\mathrm{C}$ is actinolite, $\mathrm{T}$ is tremolite and $\mathrm{M}$ is mica).

\section{DISCUSSION}

Mineralogical aspects: Figure 5 depicts the distribution pattern of minerals contained in the tailings dump mount. The tailings dump contained metals as well as pyrite and other sulfur minerals. These could, when associated with other weathering products, dissolve and wash away both vertically and horizontally into soils. Researchers at other mining sites (Al and Blowes, 1999; Blowes et al., 1995) have observed similar mineralogical trends. The slopes of the tailings dump serves as migratory pathways for ions of $\mathrm{SO}_{4}{ }^{2-}, \mathrm{CO}_{3}{ }^{2-}, \mathrm{Cl}^{-}, \mathrm{NO}_{3}{ }^{-}, \mathrm{PO}_{4}{ }^{2-}, \mathrm{Cd}, \mathrm{Co}, \mathrm{Cr}, \mathrm{Cu}$, $\mathrm{Fe}, \mathrm{Ni}$, Se, and $\mathrm{Zn}$ to have been leached through labile corridors to the subsurface environments where applicable (Ekosse et. al., 2003). In a related study, the $\mathrm{pH}$ of soils around the Selebi Phikwe area was determined and found to be in the range of 3.5 to 6 (Ekosse et. al., 2003). The soils close to the tailings dump and smelter/concentrator plant had very high $\mathrm{pH}$ (between 3.5 and 4.5), compared to soils from other areas (between 5 and 6), around Selebi Phikwe (Ekosse et. al., 2003). The high acidity in soils was due to the leaching of sulfur-rich minerals contained in tailings dump (Ekosse et. al., 2003). High acidity in the mine drainage water could be attributed to bacterially catalyzed oxidation of pyrite $\left(\mathrm{FeS}_{2}\right)$ and chalcopyrite $\left(\mathrm{CuFeS}_{2}\right)$, leading to the dissolution of many other sulfide minerals (Bain et. al., 1995). Dissolved heavy metals have the tendency of contaminating the surrounding soils mainly by oxidation Singh et. al., 1999; Buseck and Posfai, 1999; Kozák et. al., 1995). Oxidizable heavy metals are associated with mineral sulfides. Sulfide oxidation reactions from pyrrhotite oxidation are as follows, according to Blowes et al., (1995):

$\mathrm{Fe}_{(1-\mathrm{x})} \mathrm{S}+2 \mathrm{O}_{2} \rightarrow(1-\mathrm{x}) \mathrm{Fe}^{2+}+\mathrm{SO}_{4}^{2-}$

The $\mathrm{Fe}^{2+}$ shown in equation 2 is further oxidized to $\mathrm{Fe}^{3+}$ as follows

$4 \mathrm{Fe}^{2+}+\mathrm{O}_{2}+4 \mathrm{H}^{+} \rightleftharpoons 4 \mathrm{Fe}^{3+}+2 \mathrm{H}_{2} \mathrm{O}$

Further oxidation and hydrolysis of pyrrhotite results in goethite precipitation as indicated in the equations of reaction below:

$\mathrm{Fe}_{(1-\mathrm{x}) \mathrm{S}}+(8-2 \mathrm{x}) \mathrm{Fe}^{3+}+4 \mathrm{H}_{2} \mathrm{O} \rightleftharpoons(9-3 \mathrm{x}) \mathrm{Fe}^{2+}+\mathrm{SO}_{4}{ }^{2-}+8 \mathrm{H}^{+}$ (3)

$\mathrm{Fe}_{(1-\mathrm{x})} \mathrm{S}+(2-2 \mathrm{x}) \mathrm{Fe}^{3+} \rightleftharpoons(3-3 \mathrm{x}) \mathrm{Fe}^{2+}+\mathrm{S}$
$4 \mathrm{Fe}^{3+}+\mathrm{O}_{2}+6 \mathrm{H}_{2} \mathrm{O} \rightleftharpoons 4 \mathrm{FeOOH}+8 \mathrm{H}^{+}$ 


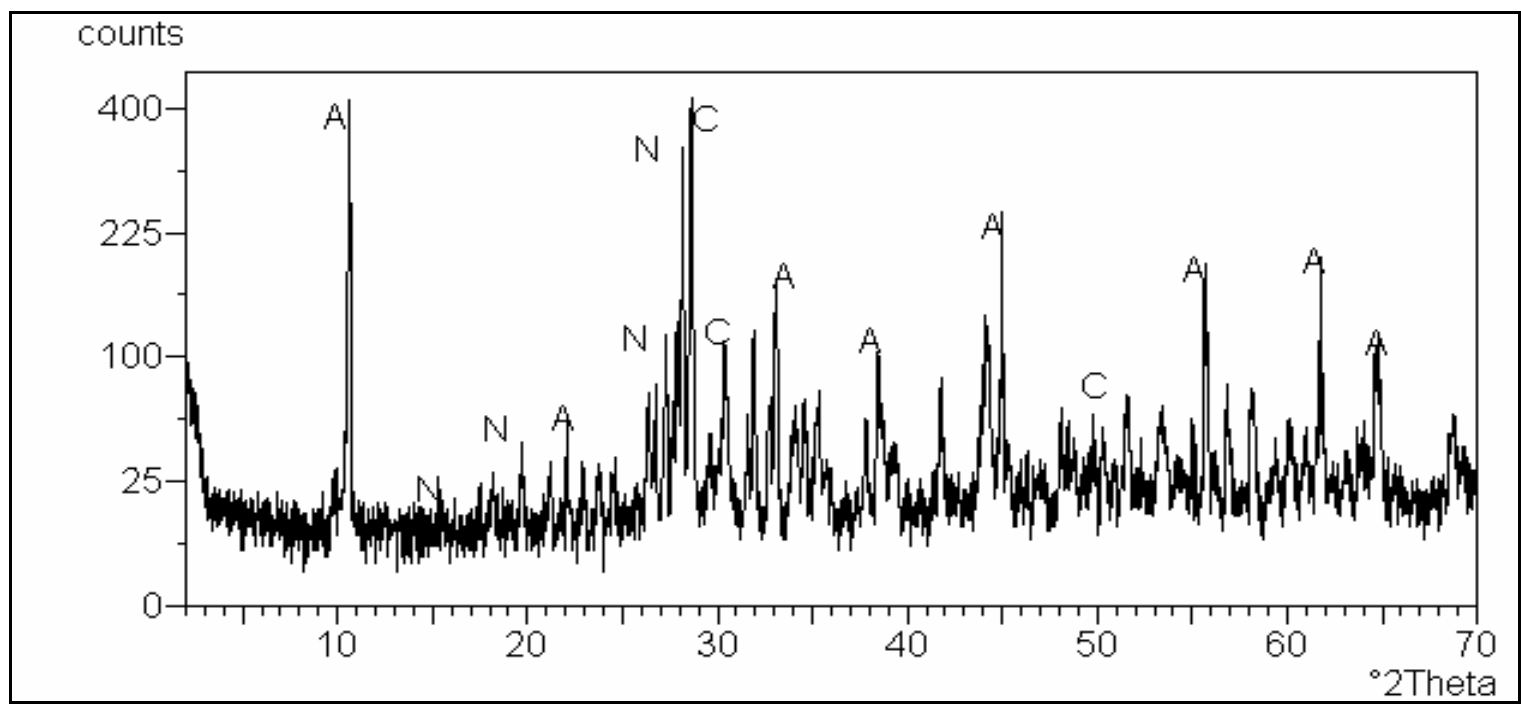

Fig 3: X-ray powder diffractogram of representative tailings dump sample obtained from site two of tailings dump (A is actinolite, C is cristobalite and $\mathrm{N}$ is nickelblodite).

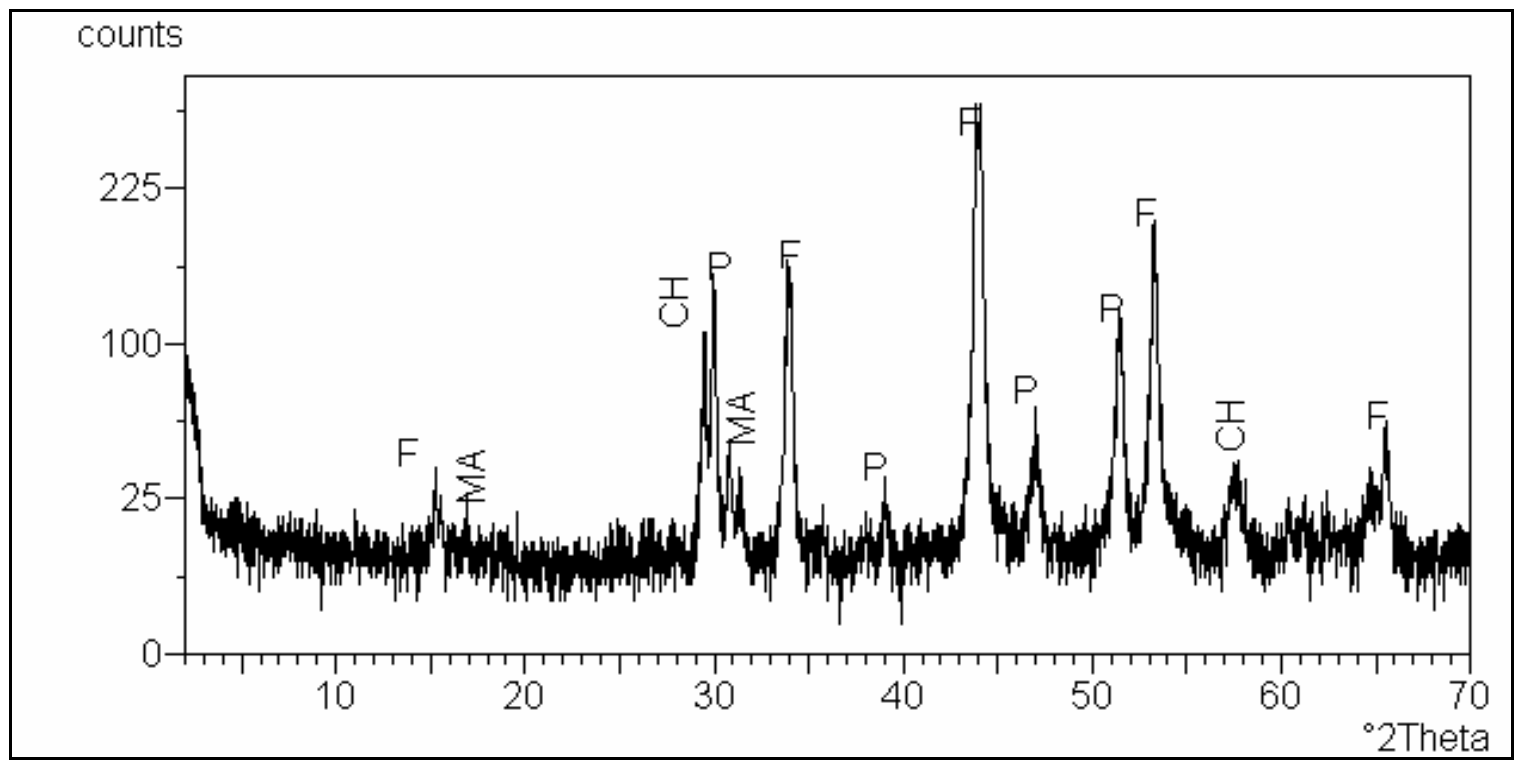

Fig 4 X-ray powder diffractogram of representative tailings dump sample obtained from site three of tailings dump (F is pyrrhotite, $\mathrm{P}$ is pentlandite, MA is malachite and $\mathrm{CH}$ is chalcopyrite).

Environmental implications: Tailings dump from Ni$\mathrm{Cu}$ mining and processing is known to promote acid mine drainage (AMD) (Blowes et al., 1995). Groundwater is consequently contaminated and the fauna and flora of the environment are affected (Kozák et. al., 1995; Blowes et. al., 1992; De Vos et. al., 1995. AMD may be defined as drainage occurring as a result of sulfide oxidation in rock exposed to air and water (Blowe et. al., 1994; Blowes et al., 1995; Benner et. al., 1997). The rocks become acidic in a low $\mathrm{pH}$ environment, leading to precipitation of ions including those of heavy metals. Pyrrhotite and pyrite in tailings dump are oxidized on exposure to water to form sulfate and sulfuric acid as indicated in equations 7 and 8 below (Blowes et al., 1995a; Benner et. al., 1997; Al et. al., 1994; $\mathrm{Al}$ et. al., 1994a):

$2 \mathrm{FeS}_{2}+16 \mathrm{H}_{2} \mathrm{O} \rightarrow 2 \mathrm{FeSO}_{4}+2 \mathrm{H}_{2} \mathrm{SO}_{4}+14 \mathrm{H}^{+}(6)$

$4 \mathrm{FeSO}_{4}+10 \mathrm{H}_{2} \mathrm{O}+\mathrm{O}_{2} \rightarrow 4 \mathrm{Fe}(\mathrm{OH})_{3}+4 \mathrm{H}_{2} \mathrm{SO}_{4}$ 
The acidification reactions could be accelerated by the presence of the bacterium Thiobacillus ferroxidans, the absence of neutralizing minerals such as calcite $\left(\mathrm{CaCO}_{3}\right)$, and release of heavy metals into their ionic state (Blowes et. al., 1998). Piles of tailings dump around the concentrator/smelter plant remain for years without proper disposal. During stockpiling, ions of heavy metals leach into the soils and water bodies, and could eventually be absorbed by plants. The grains of tailings dump observed at Selebi Phikwe were subangular, depicting limited transportation from source and also indicative of less aggressive leaching activities taking place as observed in Sundbury and Danodar river (Bain et. al., 1995; Singh et. al., 1999). Mineral orebodies and tailings dump release particles into the atmosphere through convectional forces with wind energy as a vector agent (Buseck and Posfai, 1999). More significant, however, are wastes released from tailings dump into the soils, which eventually influence the concentrations of heavy metals (Kozák et. al., 1995), contained in living organisms. Finer particles from the tailings dump could be windblown to distant environments, and eventually affect the ecosystem. Tailings dump from $\mathrm{Ni}-\mathrm{Cu}$ mines and smelter/concentrator plants leach out ions of heavy metals that could contaminate soils and cause the development of dead zones; depleted of vegetative growth.

Aspects of pollution management: Degradation of water quality in surface and ground waters in contact with an acid producing tailings dump poses as a major environmental problem associated with AMD. The water $\mathrm{pH}$ is lowered by the alteration of sulfide minerals and the release of heavy ions such as $\mathrm{Cd}$, $\mathrm{Co}, \mathrm{Cr}, \mathrm{Cu}, \mathrm{Fe}, \mathrm{Ni}$, Se and $\mathrm{Zn}$. The residual sulfides contained in tailings dumps have to be addressed in order to alleviate possible contamination of surface and ground water bodies (Mayer et. al., 1999). The discharge run-offs from S-rich tailings dumps are unsuitable for irrigation, stock weathering, drinking water, or recreational use.

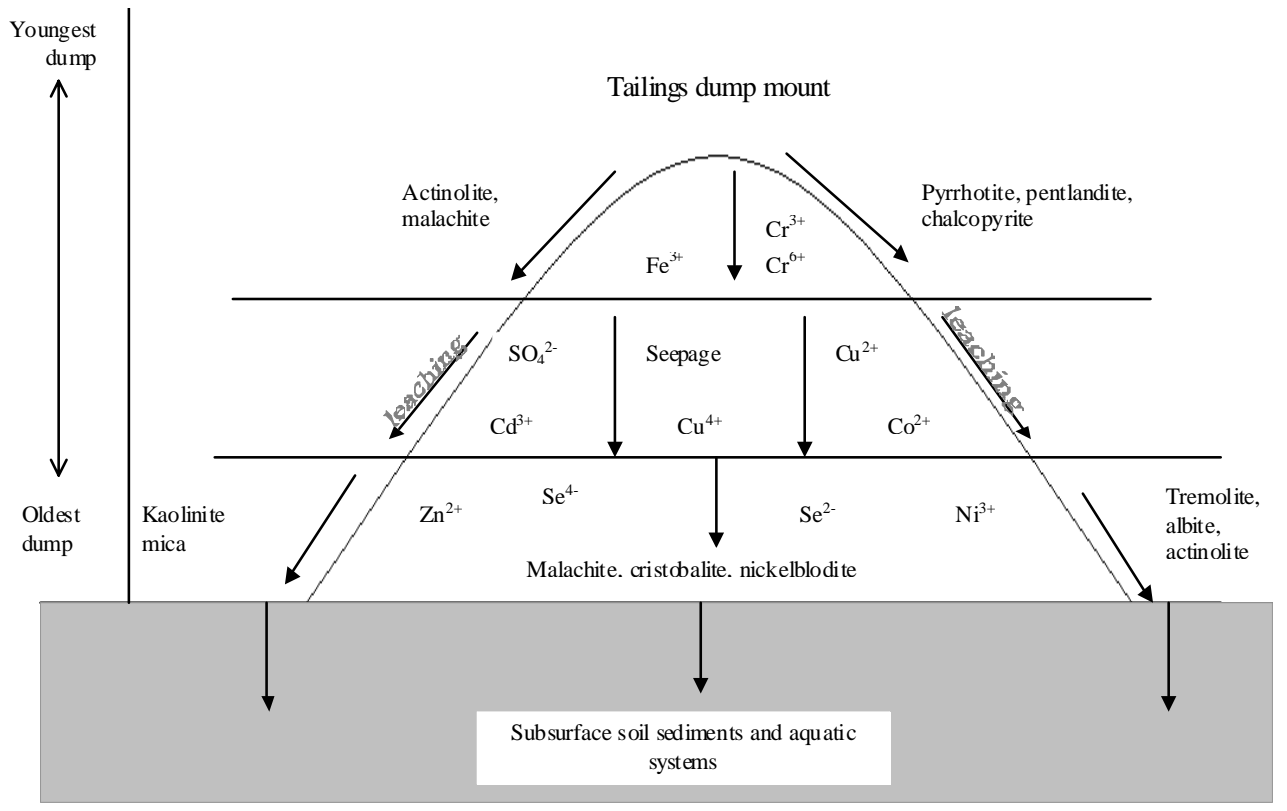

Fig 5: Distribution pattern of minerals contained in tailings dump mount.

Implementing phytoremediation could reduce passive sorption of metals, and metabolic mechanism contaminant levels of heavy metals in soils and plants at Selebi Phikwe and phytomining techniques as explained by Chaney et al. (1997). Phytoremediation as investigated and discussed by Salt et al. (1996), Cunningham et al. (1995), and Chaney et al. (1995), is a potential practical and more cost effective technology. Phytoremediation does have advantages which include non destruction and non destabilization of site, low environmental impact, favorable esthetics, continuous in situ generation of biomass, ability of living plant cells to supplement of metal uptake and detoxification (Nedelkoska and Doran, 2000). Sulfides at Selebi Phikwe are oxidized with the aid of Thiobacilli ferroxidans under favorable geochemical conditions, thereby promoting acidified environments (Chai et. al., 2000). In an effort to reduce growing environmental concerns of AMD at Selebi Phikwe, desulfurization is suggested. The desulfurized tailings can be used as cover material, thereby reducing rehabilitation costs by a factor of between $10 \%$ and $35 \%$ (Bussiere et. al., 1997; Bussiere et. al., 1998). However an effective 
surface water drainage system as discussed by Gatzweiler et al. (2001), should be part of the remediation design. Furthermore, chemical stabilization (Eusden et. al., 2001), could also be considered as a possible complimentary clean-up technique at Selebi Phikwe.

Conclusions: This study focused on mineralogically characterizing the tailings dump at the Selebi Phikwe $\mathrm{Ni}-\mathrm{Cu}$ mine area in an attempt of understanding the influence of its mineralogy on the immediate surrounding environment. Minerals identified in the tailings dump included nickelblodite, pyrrhotite, quartz, pentlandite, malachite, chalcopyrite, actinolite, cristobalite, tremolite, kaolinite, mica and albite. Nickelblodite and malachite not occurring in the orebodies, were mineralized from the primary ore minerals in the tailings dump. The S-rich minerals in tailings dump could be the principal factor responsible for AMD in the area. Due to the fact that tailings dumps are main sources of AMD (Galan et. al., 1999), adequate control measures are necessary in limiting the spread of contaminants in the surrounding environments. The steps obviously taken by the BCL authorities in containing their tailings dump are in conformity to basic principles of environmental management of tailings dump as referred to Galan et al. (1999), and Jambor and Blowes (1998).

\section{REFERENCES}

Al T.A. and Blowes D.W., 1999. The hydrogeology of a tailings impoundment formed by central discharge of thickened tailings: implications for tailings management. Journal of Contaminant Hydrology, 38: 489-505.

Al T.A., Blowes D.W. and Jambor J.L., 1994. The geochemistry of mine-waste pore water affected by the combined disposal of natrojarosite and base-metal sulfide tailings at Kidd creek, Timmins, Ontario. Can. Geotech. Journal. 31: 502-512.

Al T.A., Blowes D.W. and Jambor J.L., 1994. The pore-water geochemistry of the $\mathrm{Cu}-\mathrm{Zn}$ mine tailings at Kidd Creek, near Timmins, Ontario, Canada. Paper presented at the International land reclamation and mine Drainage Conference and the $3^{\text {rd }}$ International Conference on the abatement of acid mine drainage held 24-29 April, 1994, Pittsburgh, PA, USA. Pp 10,

Bain J.G., Blowes D.W., and Robertson W.D.,1995. The hydrogeochemistry of a sand aquifer affected by discharge from the nickel Rim tailings, Sudbury, Ontario. Paper presented at the Conference on Mining and the environment, Sudbury, Ontario. 28 May-1 June 1995

Benner S.G., Blowes D.W. and Ptacek J. A., 1997. Full-scale porous reactive wall for prevention of acid mine drainage. Ground Water Monitoring and Remediation. 17: 99-107.

Blowes D.W., Jambor J.L., Appleyard E.C., Reardon E.J. and Cherry J.A., 1992. Temporal observations of the geochemistry and mineralogy of a sulfide-rich mine-tailings impoundment, Heath Steele Mines, New Brunswick. Explor. Mining Geol, 1: 251-264.

Blowes D.W., Ptacek C.J., Frind E.O., Johnson R.H., Robertson W.D. and Molson J.W., 1994. Acidneutralization reactions in inactive mine tailings impoundments and their effect on the transport of dissolved metals. Paper presented at the International land reclamation and mine Drainage Conference and the $3^{\text {rd }}$ International Conference on the abatement of acid mine drainage held 24-29 April, 1994. Pittsburgh, PA, USA. Pp 10.

Blowes D.W., Ptacek C.J., Cherry J.A., Gillham R.W. and Robertson W.D., 1995. Passive remediation of groundwater using in-situ treatment curtains. In: Acar Y. B. and Daniel D. E. (Eds), Geoenvironment 2000, Characterization, Containment, Remediation, and Performance in Environmental Geotechnics, American society of Civil Engineers, New York, USA. Geotechnical Special Publication. 46: 1588-1607.

Blowes D.W., Al T.A.., Lorite L., Gould W.D. and Jambor J.L., 1995. Microbiological, chemical, and mineralogical characterization of the Kidd Creek Mine Tailings Impoundments, Timmins area, Ontario. Geomicrobiology Journal, 13: 1331.

Blowes D.W., Jambor J.L. and Hantong-Fong C.J., 1998. Geochemical, mineralogical and microbiological characterization of a sulfidebearing carbonate-rich gold-mine tailings impoundment, Joutel, Quebec. Applied Geochemistry. 13: 687-705

Brown P.J., 1987. Petrogenesis of Ni-Cu orebodies, their host rocks and country rocks, Selebi Phikwe, Eastern Botswana. Unpublished PhD thesis, University of Southampton, England. 
Buseck P.R. and Posfai M., 1999. Airborne minerals and related aerosol particles: Effects on climate and the environment. Colloquium paper presented at the National Academy of Sciences on Geology, Mineralogy, and Human Welfare, Held Nov 8-9, 1998, Arnold and Mabel Beckman Centre, Irvine, CA, USA. 96, 33723379.

Bussiere B., Bois D. and Benzaazoua M., 1997. Valorisation des residus miniers generateurs de drainage minier acide par la desulfurisation. Compte rendu du 20 eme Symposium sur les eaux usee, $9^{\text {eme }}$ Atelier sur l'eau potable et 13eme Congres de l'Est du Canada sur la qualite de l'eau (ACQE) Collection Environment de I'Universite de Montreal. 10, 275-289.

Bussiere B., Benzaazoua M., Aubertin M., Bois D. and Servant S., 1998. Valorisation des residus miniers: une approche integre - Phase II. Final report submitted to the Ministere des Resources Naturelles du Quebec. Programme NEDEM, 1998, pp198.

Chai L., Wei W. and Okido M., 2000. Technical note. Studies on effect of $\mathrm{Cu}(\mathrm{II})$ on growth with Thiobacillus Ferrooxidans using series piezoelectric quartz crystal. Minerals Engineering. 13: 969-972.

Chaney R.L., Brown S.L., Li Y.M., Angle J.S., Homer F.A. and Green C.E., 1995. Potential use of metal hyperaccumulators. Mining and Environmental Management. 3: 9-11.

Chaney R.L., Malik M., Li Y.M., Brown S.L., Brewer E.P., Angle J.S. and Baker A.J.M., 1997.Phytoremediation of soil metals. http://www.soils.wise.edu/ 10pp,

Cunningham S.D., Berti W.R. and Huang J.W., 1995. Phytoremediation of contaminated soils. Trends Biotechnol.; 13: 393-397.

De Vos K.J., Blowes D.W., Robertson W.D. and Greenhouse J.P., 1995. Delineation and evaluation of a plume of tailings derived water, Copper Cliff, Ontario. Conference on Mining and the Environment, Sudbury, Ontario. 28 May1 June, 1995. Conference Proceedings. 2: 673683.

Ekosse G, Van den Heever D, De Jager L and Totolo O., 2003. Environmental mineralogy of soils around Selebi Phikwe nickel-copper plant,
Botswana. International Journal of Environmental Studies, 60, 251-262

Ekosse G., Van den Heever D. J., de Jager L., and Totolo O (2004) Environmental chemistry and mineralogy of particulate air matter around Selebi Phikwe copper-nickel plant, Botswana. Minerals Engineering 17, 349-353

Eusden J. D., Gallagher L.., Eighmy T. T., Crannell B. S., Krzanowski J. R., Butler L. G., Cartledge F. K., Emery E. F., Shaw E. L. and Francis C. A., 2001. Petrographic and spectroscopic characterization of phosphate-stabilized mine tailings from Leadville, Colorado. Waste Management.. 22: 117-135.

Galan E., Carretero M.I. and Fernandez-Caliani J.C., 1999. Effects of acid mine drainage on clay minerals suspended in the Tinto River (Río Tinto, Spain). An experimental approach. Clay Minerals. 34: 99-108.

Gallon M.L., 1986. Structural re-interpretation of the Selebi Phikwe nickel-copper sulfide deposits, Eastern Botswana. In Anhaeusser C.R. and Maske S. (Eds) Mineral deposits of southern Africa. Vols 1\&2, Geol Soc S Afr., Johannesburg 1663-1669.

Gatzweiler R., Jahn S., Nubert G. and Paul M., 2001. Cover design for radiative and AMD-producing mine waste in the Ronnburg area, Eastern Thuringa. Waste Management. 21: 175-184.

Jambor J.L .and Blowes D.W., 1998. Major-element variations in the reactive sulfide-rich tailings at the Waite Amulet Mine site, Noranda area, Quebec, Canada. American institute of Mining Eng. Process Mineralogy. 9: 511-523.

Kozák J., Janku J. and Jehlicka J., 1995. The problems of heavily polluted soils in the Czech Republic: A case study. In Salmons W., FrÖstener U. and Mader P. (Eds) Heavy metals: Problems and solutions. Springer. 287-300

Mayer K.U., Benner S.G. and Blowes D.W., 1999. The reactive transport model MIN3P: Application to acid mine drainage generation and treatment - Nickel Rim Mine site, Sudbury, Ontario. Paper presented at the $2^{\text {nd }}$ Conference on mining and the environment held at Sudbury on 13-15 Sept 1999. 
National Census, 1991. National population and housing census report. Botswana Government, Gaborone, Botswana.

Nedelkoska T.V. and Doran P.M., 2000. Characteristics of heavy metal uptake by plant species with potential for phytoremediation and phytomining. Minerals Engineering. 13: 549561.

Nkoma J.S. and Ekosse G., 1998. Study of chalcopyrite $\mathrm{CuFeS}_{2}$, pentlandite $(\mathrm{Fe}, \mathrm{Ni})_{9} \mathrm{~S}_{8}$, and pyrrhotite $\left(\mathrm{Fe}_{1-\mathrm{x}} \mathrm{S}\right)$ obtained from $\mathrm{Cu}-\mathrm{Ni}$ orebodies. The Abdus Salam Centre for Theoretical Physics, Trieste, Italy. IC/98/41.

Nkoma J.S. and Ekosse G., 1999. X-ray diffraction study of chalcopyrite $\mathrm{CuFeS}_{2}$, pentlandite $(\mathrm{Fe}, \mathrm{Ni})_{9} \mathrm{~S}_{8}$, and pyrrhotite $\left(\mathrm{Fe}_{1-}\right.$ ${ }_{\mathrm{x}} \mathrm{S}$ ) obtained from Cu-Ni orebodies. J. Phys: Condensed Matter, 11: 121-128.
Nkoma J.S. and Ekosse G., 2000. X-ray powder diffraction study of transition sulfide minerals contained in Ni-Cu orebodies from Selebi Phikwe, southeastern Botswana. Botswana Notes and Records, 32: 165-176.

Salt D.E., Blaylock M., Kumar P.B., Dushenkov S., Ensley B.D., Chet I. and Raskin I., 1996. Phytoremediation: A novel strategy for the removal of toxic metals from the environment using plants. Bio/Tech. 13: 468-474.

Singh A.K., Hasnain S.I. and Banerjee D.K., 1999. Grain size and geochemical partitioning of heavy metals in sediments of the Damodar River - a tributary of the lower Ganga, India. Environmental Geology, 39: 90-97. 